American Journal of Agricultural and Biological Sciences 3 (1): 315-320, 2008

ISSN 1557-4989

(C) 2008 Science Publications

\title{
Waste Management: A Case Study of Ongoing Traditional Practices at East Calcutta Wetland
}

\author{
Shaon Raychaudhuri, Madhusmita Mishra, Poulomi Nandy and Ashoke R Thakur \\ Department of Biotechnology, West Bengal University of Technology, BF-142, \\ Sector 1, Salt Lake, Calcutta-700064, India
}

\begin{abstract}
Calcutta has a unique waste management system which uses the traditional non conventional practice for treating both the solid as well as soluble waste for its 12 million inhabitants . It not only detoxifies the waste but also generates resources for the existing society in form of employment as well as edibles like sufficient vegetable, fish as well as paddy for consumption. The elemental analysis of these products showed no metal toxicity due to their cultivation using waste resource. Thus East Calcutta Wetland can be sited as the best example of integrated resource recovery.
\end{abstract}

Key words: East Calcutta Wetland, Bheri, Wastewater purification, Integrated Resource Recovery

\section{INTRODUCTION}

Calcutta has been described by many as ecologically subsidized city for its two special geographical features. One is the existence of the River Hoogly on the west as the source of drinking water, the other is the vast low lying area on the east towards which the city is inclined and plays the role of a sink ${ }^{[1]}$. This 12,500 hectare area which is located $22^{\circ} 27^{\prime} \mathrm{N}$, $88^{\circ} 27^{\prime} \mathrm{E}$ is known as the East Calcutta Wetland $(\mathrm{ECW})^{[2]}$ and was designated as a Ramsar site in 2002.

Cities consume resources and produce both solid and liquid waste. Waste may normally be defined as any material or energy which cannot be economically used, recovered or recycled at a given time and place. Thus, every city of the world must find a way of dealing with its waste. But can this waste be treated as a useful resource instead of a hazard to the public? The answer to this important question was provided by the 20,000 natural ecologists [farmers and fisherman] of $\mathrm{ECW}^{[3]}$. It is because of them that sewage has taken on a new meaning for Calcutta.

East Calcutta Wetland is an example of resource recovery system where usage of city sewage for traditional practices of fisheries and agriculture is practiced. Waste recycling includes four principal resource recovery practices: garbage vegetable farms; wastewater-fed fishponds; paddy fields using fishpond effluent; and sewage-fed brackish water aquaculture. The daily sewage and wastewater generation by the Municipal Corporation is roughly 600 million litres and more than 2,500 tonnes of garbage. The wastewater flows through underground sewers to pumping stations in the eastern fringe of the city and is then pumped into open channels. Thereafter workers of some 286 sewage fed fisheries, agricultural and solid waste farms for vegetables and paddy in the wetlands take over ${ }^{[4]}$.

The Bheris - as they are locally called, are shallow flat bottomed wastewater fed lagoon type of ponds, which vary between $50-150 \mathrm{~cm}$ in depth and can be as large as $40-50$ ha in size ${ }^{[5]}$. The basin being shallow allows full vertical circulation of water to the surface where algal blooms occur. This is also favorable for photosynthesis, as this depth gives a better ratio between pond volume and pond surface than a deeper pond. This helps provide sufficient oxygenation to allow for efficient BOD (Biochemical Oxygen Demand) and pathogen/fecal coliform reduction. It also generates an abundant quantity of algal photosynthetic oxyge $^{[2]}$. The photosynthetic activities in the pond is one of the reasons for the purification of sewage. The water from the Raw Sewage Canal is drained into the Bheri, where it undergoes purification before being used for irrigation. The essential factors in the purifying process are the shallow ponds [which act as stabilization tanks], abundant water hyacinth [accumulates metals], the sun rays penetrating to the bottom of the pond, the wind and multiple forms of plankton, algae as well as bacteria.

Bheri: a prime site for bioremedial activity: The geographical location of Calcutta provides it with a hot and humid climate throughout the year. The tropical climate along with average rainfall of $1650 \mathrm{~mm}-90 \%$ from June to October, ensures the area to act as a

Corresponding Author: $\quad$ Shaon Raychaudhuri, Lecturer of Department of Biotechnology, West Bengal University of Technology, India, 700064 
natural incubator for a diverse group of microbes, thus making it a biodiversity rich spot.

ECW being the world's largest natural recycling center for soluble and solid wastes, it is expected to be rich source of bioremediants. The microbial resource mapping of this important Ramsar Site indicated the presence of microorganisms from 12 different main bacterial phyla thus revealing the rich natural microbial resource at East Calcutta Wetland ${ }^{[6]}$. This variation in population at the different sites of ECW points towards the underlying bioremedial activity operating there. Presence of Actinobacteria and Fermicutes indicates the possibility of the phenomenon of nitrophenol; nitroaromatic compound; pesticide and herbicide degradation. Along with these wastes since agricultural activity is carried out here, these microbes are also involved in decomposition and humus formation. Proteobacteria present at ECW would be involved in bioremediation of heavy metals, degradation and recycling of woody tissue of plants and biodegradation of oil contaminated soil and toxic compounds. They are involved in nitrogen fixation along with the Cyanobacteria in Bheris.

Some of the above phyla are reported to produce enzymes and antimicrobial compound. These findings indicate towards the probable presence of metal accumulating [7], oil degrading, antimicrobial compound producing as well as enzyme producing bacteria which can be commercially exploited ${ }^{[8]}$.

Purification of Bheriwater and the possible explanations: The organic loading rate in these fishponds varies between $20-70 \mathrm{~kg}$ per hectare per day [in the form of BOD]. The cumulative efficiency of reducing the $\mathrm{BOD}$ of the sewage water is above $80 \%$ on an average. The solar radiation, which is about 250 langlays a day, is sufficient for photosynthesis. Algae has the capability to utilize light energy and capture and concentrate nutrients from dilute aqueous solutions. Some of the algae are capable of growing commensally in an ecosystem with waste-oxidizing bacteria. The results of the commensal metabolism are the release of oxygen and synthesis of bacterial degradation products into new, protein-rich plant material. Algae and bacteria can be used for the treatment and conversion of wastes from human and animal origin into forms useful for fish and animal feeds ${ }^{[9]}$.

Reduction of BOD takes place because of a unique phenomenon of algae-bacteria symbiosis where energy is drawn from algal photosynthesis. Therefore consumption of conventional energy is minimized. Each hectare of a shallow waterbody can remove about $237 \mathrm{~kg}$ of BOD per day. This helps in the reduction of coliform bacteria prone to be pathogenic which even conventional mechanical sewage treatment plants may not be able to fully eliminate. The effluents from the fishponds is then made to drain further southeast where the cultivable lands used as vegetable and paddy fields have been strategically located to benefit from the use of the effluent ${ }^{[10]}$.

In another way, the solar energy is trapped by a dense population of plankton which in turn are consumed by the fishes. The plankton play a significant role in degrading the organic matter. But the overgrowth of the planktons becomes a problem for pond management since they causes algal bloom. It is at this critical phase of the ecological process that the fish plays an important role by grazing on the plankton. The two fold role played by the fishes is indeed crucial they maintain a proper balance of the plankton population in the pond and also convert the available nutrients in the wastewater into readily consumable form (fish) for humans. The fish farmers of ECW have developed such a mastery of these resource recovery activities that they are easily growing fish at a yield which is 2 to 4 times higher than normal ponds and production cost unmatched by any other freshwater fish ponds of this country ${ }^{[10,11]}$.

Fecal Coliform Bacteria removal: Fecal coliform bacteria, particularly pathogenic members of the family Enterobacteriaceae, and fecal viruses are commonly used as indicators of fecal bacterial pathogens. Fecal bacterial removal is largely due to the activities of the pond algae. When the algae are photosynthesizing rapidly, their demand for $\mathrm{CO}_{2}$ outstrips its supply from bacterial metabolism and this leads to carbonate and bicarbonate dissociation. The resulting $\mathrm{CO}_{2}$ is fixed by the algae and the hydroxyl ions accumulate to raise the $\mathrm{pH}$ rapidly which is lethal to fecal bacteria. High levels of dissolved oxygen (due to algal photosynthesis) and high visible light intensities, in the presence of dissolved humic substances are fatal to fecal bacteria. One of the unique contributions of algae is their daily elevation of $\mathrm{pH}$ in the pond. $\mathrm{A} \mathrm{pH}$ of 8 to 9.2 for 24 hours is known to provide a $100 \%$ kill of $E$. coli and presumably most pathogenic bacteria ${ }^{[12]}$. But this process though cost effective has its own limitations. The algal growth and waste utilization process just described is limited to climatic regions where ambient solar energy is greater than $200 \mathrm{cal} / \mathrm{cm}^{2} /$ day, mainly as found in tropical countries. Another restraint is the requirement that the algal growth potential of the wastewater be sufficiently great to support photosynthetic oxygen production. Retention of wastewater in the ponds before the initial stocking of fish for a considerable period of time allows bacteria to work upon the organic matter in the sewage and decompose the organic waste. The growth of these beneficial bacteria is supported by the algae that thrives 
in these shallow ponds under the ample sunshine ${ }^{[1]}$. The quality of the wastewater depends on the quantity of nutrients present. In case of low nutrient content, external input is essential ${ }^{[10]}$. These bheris show the features of both facultative (but aerobic at all times) as well as maturation ponds ${ }^{[5]}$. The biochemical reactions occurring in the facultative pond include photosynthesis, aerobic oxidation, organic acid formation, methanogenesis, hetetrophic nitrification as well as denitrification ${ }^{[12]}$.

Role of Aquatic Weeds: Phytoremediation, the process of using green plants to remove, contain or render harmless environmental contaminants is known to function efficiently in this ecosystem. There are various mechanisms by which plants remove toxic materials from the environment namely phytoextraction (which involves using pollutant accumulating plants to remove metals or organics from soil), phytodegradation (where plants are used to degrade organic pollutants), rhizofiltration (in which the plant roots are used to absorb or adsorb pollutants, mainly metals from water and aqueous waste stream), phytostabilization (the plants reduces bioavailability of pollutants in environment) and phytovolatilization (plants used to volatilize pollutants).

Plants are also involved in the purification process operating in these traditional wastewater fed aquaculture. They are known to capture solar radiation, perform nitrogen fixation as well as accumulate heavy metals. They are involved in production and transport of oxygen. Some of their secretions show bacteriostatic properties. Plant roots release compounds including simple sugars, amino acids, aliphatics, aromatics that stimulate the growth and metabolism of specific microbial communities which accelerate the bioremediation process ${ }^{[13]}$. They provide attachment surface and create micro-regions with favorable conditions for diverse micro - organisms. They act as temperature buffers by insulation as well as shading and at the same time prevents undesirable algal growth by shading ${ }^{[7]}$.

Water Hyacinth plays a special role in the functioning of this complex ecosystem. Besides preventing erosion of the pond bank by breaking up the surface waves and providing shade to the fishes during summer, its main function is to leach out heavy metal ions from the surrounding water ${ }^{[10]}$. Its roots are well known absorbers of heavy metal present in sewage water. Thus periodic harvesting of these weeds leads to successful bioremediation ${ }^{[3]}$. Water Hyacinth is mainly concerned with rhizofiltration; where plant roots act as "biocurtains" or "biofilters" for the passive remediation of wastewater.

\section{Bheri: A source for product generation}

Fish Cultivation: The high productivity of the sewage fed fish ponds is due to high content of nutrients in the wastewater, while the high alkalinity, stimulates the production of phytoplanktons, a primary product in the fish food chain.

The hydraulic nature of the wastewater fed fishponds of the wetlands has unique properties - it is neither lentic nor lotic. Wastewater flows into the fishponds through inlet channels in batches and their outflow is similarly regulated. In case of large ponds, around $40-45$ ha, the wastewater inflow is almost continuous and the water regime becomes lotic ${ }^{[5]}$. The few important points in the functioning of the waste water fed fisheries are the unique architecture and preparation of the pond as well as the exact timing of release of fish into these bodies ${ }^{[11]}$. The wetlands \& particularly the tidal river Bidyadhari, was historically used to farm salt water fish. With the silting of the river and increasing volumes of sewage disposed into the area, water salinity reduced to almost half, creating ideal conditions for fresh fish culture ${ }^{[5]}$.

The preparation of the fish pond can be divided into 5 major phases. Phase 1 involves the pond preparation which is the most crucial point in the Bheri architechture, it is done during the coolest months of the year. It involves complete drainage of existing pond water which ensures proper cleaning of all the previous remnants. Sunlight is used to dry up the pond and is presumed to act as a disinfectant by killing some of the parasites that affect fish production. Tilling and desilting the bottom of the Bheri ensures that the depth of the Bheri is maintained at 50 to $150 \mathrm{~cm}$ which mandatory for the purification process to operate. Silt traps which are $3 \mathrm{~m}$ wide and $30-40 \mathrm{~cm}$ deep pits are also generated around the bheri edges. They harbour the deposited silts of the ponds. From time to time silt is removed from the pits and used to repair the pond dikes $^{[10]}$. Phase 2 is the primary fertilization which is done during the middle of February. The ponds are filled with wastewater and the water is allowed to stand, so that it undergoes natural purification through processes mediated by microscopic biota, before fishes are stocked. The water is stirred intensely to remove anaerobic conditions in the sediments and ensure aerobic digestion. This promotes the development of benthic organisms which serve as fish feed. Phase 3 beginning in mid March is the fish stocking. Here water quality is tested by introducing a small number of fishes in the pond before introducing the actual fish stock. Only on obtaining the desirable result the proper stocking is done which is four times the quantity of the test fish, but it also depends on the fish species. Phase 4 
is the stage of secondary fertilization where sewage and wastewater is introduced from time to time throughout the growth cycle of fishes. The nature, duration and volume of water introduced depends upon the size of the pond. Phase 5 is the final stage which involves harvesting and continues for the rest of the year depending on the fish species ${ }^{[5]}$. Three types of ponds are needed according to the stage of production - the nursery pond, rearing pond and stocking pond. Each needs a proper inflow and outflow channel management, which is mostly directed by gravity, only in some areas diesel powered pumps are used.

Since ECW acts as a natural sewage treatment plant, the entire city's waste is discharged here. Tanneries, small scale industries dealing with production of paints, electroplating, battery etc can act as source of metals like chromium, copper etc. Lead is released due to leaching of ores. The source of rubidium is mica which is found in Gulal (powdered colours) used in festive seasons. These metals are discarded to the raw sewage canal and thereby released to the water bodies and can pose a possibility of accumulation in the fish which inhabit these water bodies. To asscess the risk if any, fishes generated from these sewage fed fisheries were analyzed for the extent of metal accumulation and they were compared with those from other fresh water fed sites. This comparative analysis carried out by our group inferred no additional accumulation of metals in fishes from sewage fed bodies as compared to fresh water ones. Thus it can be concluded that the sewage fed fisheries have no added effect in the accumulation of the metals in the fishes.

Vegetable farming: Another system of waste recycling in ECW are the vegetable farms and paddy fields which sustain on the garbage and effluent from the waste water fed fisheries as manure and water for irrigation. The old solid waste dumping grounds have been converted into cultivable lands. The garbage farms yield 150 tonnes of fresh vegetables daily and the paddy fields produce 16,000 tonnes of winter paddy varieties cultivated during post monsoon period annually. The key question arising at this point is regarding the safety, quality and reliability of the method using the wastewater and solid waste for cultivation of green leafy vegetables at ECW. Different elements in green leafy vegetables like Amaranthus caudatus, Amaranthus blithum and Spinacia oleracea from ECW sites and also distant places (non-ECW sites) were studied. These vegetables were chosen because these are the most commonly consumed vegetables of this region. The concentrations for the elements: P, S, Cl, K, Ca, V, Cr, Mn, Fe, Co, Ni, Cu,
$\mathrm{Zn}, \mathrm{As}, \mathrm{Se}, \mathrm{Br}, \mathrm{Rb}, \mathrm{Sr}$ and $\mathrm{Pb}$ were determined for both the ECW and the non-ECW vegetables by our group ${ }^{[7]}$. Variations do exist in the levels of elements in the vegetables grown at ECW. The net consumption of the aforementioned elements per person per day was calculated and found to be much below the Recommended Dietary Allowance (RDA) levels in all cases. Since at ECW, the entire detoxification process is free from any type of chemical treatment and is purely driven by natural mechanisms there is little chance of the hazardous effects of chemicals fertilizers over the cultivation process. Thus the vegetables grown out of integrated resource recovery mechanism at ECW appear to be safe for human consumption. This is further corroborated by the healthy appearance of these vegetables. This result has profound implications of far reaching significance for environmental management and health economics.

Additional promises for future: The rich biodiversity of the wetland holds forward its wide application in bioremediation as well as commercial utilization. With an aim to utilize the microbial resource of the wetland for the purpose of bioremediation, isolation of different bacterial strains was carried out from different sites of ECW. Some of these strains showed extracellular production of enzymes like protease and certain other produced extracellular lipase. These enzymes were found to act effectively as additives to detergents (data not shown). In addition to this all these isolates showed accumulation of metals like $\mathrm{Ni}, \mathrm{Cu}, \mathrm{Pb}, \mathrm{Cr}$ etc. (Fig 1). The metal accumulating property of these microbes can facilitate designing of a bioremedial package for treating contaminants rich in metals.

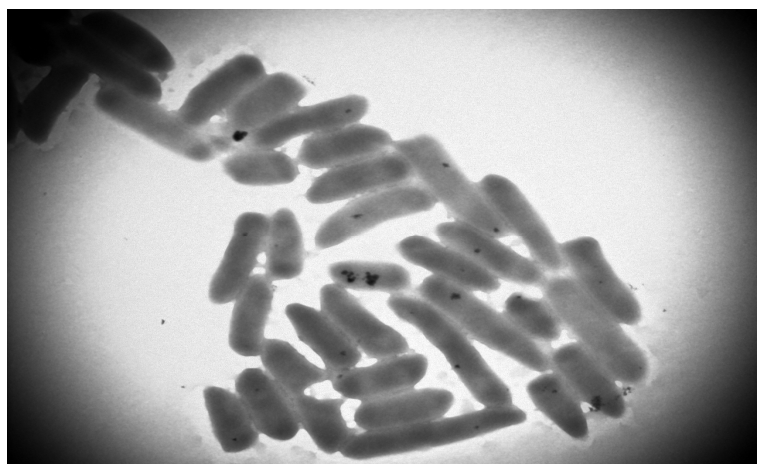

Fig 1: Unstained bacterial strain from East Calcutta Wetland under Transmission Electron Microscope showing metal deposition as electron dense particles. 
Along with the above microbes, different groups of sulfate reducing bacteria(SRB) are also isolated by our group from ECW. These SRB showed efficient reduction of soluble sulfate. Thus in a mega city like Calcutta with a population of more than 1 million and a high load of soluble sulphate resulting from air pollution as well as industrial activities, these consortia would act as an efficient bioremedial package.

\section{CONCLUSION}

In a developing country like India keeping environmental protection as the prime importance, the key points to be looked after in remediation process is availability of inexpensive resources and least potential side effects. The conventional techniques used for bioremediation have been to dig up contaminated soil and to remove it to a landfill, or it can be a chemical treatment to reduce the load of hazardous waste. But these methods have lot of drawbacks like, these chemical treatment process are highly expensive and on the other side with the increasing rate of population in this developing country it is difficult and quite expensive to find a new landfill. Keeping these points in view the best alternative to conventional clean up technologies is bioremediation. It uses relatively low cost low technology techniques which generally have a high public acceptance and can be often carried out on site. Not only in developing country, but in developed countries where land is the main crisis, bioremediation technique is the best solution.

ECW is an unique example in environmental protection and development management that is in harmony with nature and benefits are achieved at a much lower cost. The key strategy for environmental protection here is bioremediation. Taking into account the conventional strategy, the main drawback is the conventional sewage treatment plants are their being prone to damage and frequent breakdowns. Without financial assistance, no municipal bodies in the developing countries can afford to run conventional mechanical sewage treatment plants. Calcutta currently has no sewage treatment plant for its 12 million inhabitants. The sites resource recovery system, developed by local people through the ages, have saved the city of Calcutta from the costs of constructing and maintaining wastewater treatment plants. The recycling system that has developed over a century operates with minimum use of technology and engineering ${ }^{[14]}$.

Resource recovery systems on the other hand are a revenue earner. Calcutta produces 1/3 (around 8000 tonnes annually) of its requirement of fish from sewage wastewater fed lagoons, the garbage farms yield 150 tonnes of fresh vegetables on a daily basis and 16,000 tonnes of winter paddy annually ${ }^{[2]}$. In addition it provides employment to a large number of individuals. Hence Bheris and on the whole the ECW can be considered as an excellent example of wise integrated resource recovery directly utilizing technology for the benefit of environment as well as society.

In addition to environmental protection and a economy generation system, another important aspect of this area is that, it is a biodiversity rich spot. ECW is habitat to about 100 plant species, 20 rare mammals and more than 40 bird species comprising of both native as well as migratory ones are reported ${ }^{[15]}$. The total area of the ECW water body has been reduced by two thirds during the last 40 years and is still under threat now ${ }^{[16]}$. The land encroachment can pose as a threat to this rich system. Thus it needs to be saved keeping in view the immense benefits this system gives to the human society.

\section{ACKNOWLEDGEMENT}

The authors would like to acknowledge the financial support of Department of Science and Technology, India as well as Department of Biotechnology, India. They would thank Bioinormatics Infrastructure Facility (DBT, GOI supported) of West Bengal University of Technology for its computational facility. Authors would acknowledge Dr Atanu Basu of National Institute of Virology, Pune, India for the Transmission Electron Microscopy facility.

\section{REFERENCES}

1. http://www.changemakers.net/journal/98october/gh osh.cfm. (Accessed on 14th June 2007).

2. http://www.ruaf.org/no8/29_kolkata.pdf. (Accessed on 5th April 2007).

3. http://www.changemakers.net/journal/98october/py esmith.cfm. (Accessed on 14th June 2007).

4. http://www.downtoearth.org.in/Full6.asp?FolderNa $\mathrm{me}=20060915 \&$ FileNAme $=$ news $\&$ sid $=3 \&$ sec $\_i d=$ 4. (Accessed on 14th June 2007). http://www.cepis.opsoms.org/muwww/fulltext/repi nd53/calcutta/calcutta.html. Accessed on 14th June 2007.

5. Ray Chaudhuri, S. and A.R. Thakur, 2006. Microbial genetics mapping of East Calcutta Wetland. Current Science, 2 : 212-217.

6. Ray Chaudhuri, S., S. Salodkar, M. Sudarshan and A.R. Thakur, 2007. Integrated Resource Recovery at East Calcutta Wetland - how safe is these? International Journal of Agricultural and Biological Scienes, 2: 75-80 
7. Ghosh, S.K., 2004. Traditional Commercial practices in Sustainable Development \& Conservation of Man and Wetlands. Knowledge Marketplace Report. The 3rd IUCN world Conservation Congress 17-25 Nov 2004, pp: 1-6.

8. Ray Chaudhuri, S. and A.R. Thakur, 2006. Microbial DNA extraction from sample of varied origin. Current Science, 12: 1697-1700.

9. http://www.ecotippingpoints.org/indepth/indiawetl ands.html. (Accessed on 14th June 2007).

10. Amann, R.I., W.Ludwig and K.H. Schleifer, 1995. Phylogenetic identification and in situ detection of individual microbial cells without cultivation. Microbiol Rev., 59: 143-169.

11. Chung, C.T., S.L. Neimela and R.H. Miller, 1989. One-step preparation of competent E. coli transformation and storage of bacterial cells in the same solution. PNAS, 86: 2172-2175.

12. R. Sarin, D.S. Ramteke and U.A. Moghe. Manual on water and waste water analysis, pp.71-73.

13. Furedy, C. and D. Ghosh, 1984. Resourceconserving traditions and waste disposal: the garbage farms and sewage-fed fisheries of Calcutta. Conservation and Recycling, 7 (2-4): 159-165.

14. http://www.wwfindia.org/about_wwf/what_we_do/ freshwater_wetlands/our_work/ramsar_sites/east_c alcutta_wetlands_.cfm. (Accessed on 14th June 2007).

15. Chattopadhyay, K., 2001. Environmental conservation and valuation of East Calcutta Wetlands. Wetlands and Biodiversity EERC Working Paper Series: WB-2. Available: http://coe.mse.ac.in/eercrep/fullrep/wetbio/WB_FR _KunalChattopadhyay.pdf (Accessed on 15th June 2007).

16. http://www.keip.in/east_kolkata_wetland.htm. Accessed on 14th June 2007.
17. Chattopadhyay, B., A.Chatterjee and S.K. Mukhopadhyay, 2002. Bioaccumulation of metals in the East Calcutta wetland ecosystem. Aquatic Ecosystem Health and Management , 5 (2): 191203.

18. Ward, D.M., R. Weller and M.M. Bateson, 1990. Sequences reveal numerous uncultured microorganisms in a natural community. Nature, 345: 63-65.

19. Ghosh, S.K., 2004. Traditional Commercial practices in Sustainable Development \& Conservation of Man and Wetlands. Knowledge Marketplace Report. The 3rd IUCN world Conservation Congress 17-25 Nov 2004, pp: 1-6.

20. Microbial Processes: Promising Technologies for Developing Countries: Report 1979 National Research Council (NRC) Available: http://www.nap.edu/catalog/9544.html. Accessed on $15^{\text {th }}$ June 2007.

21. Tuba, E. and M. Victor. Advanced Integrated Wastewater Pond Systems (AIWPS) by Tuba Ertas and Victor M. Ponce. Available: http://ponce.sdsu.edu/aiwps.html. Accessed on $15^{\text {th }}$ June 2007.

22. Junge-Berberovic, R., 2001. Possibilities and Limits of Wastewater fed Aquaculture. GTZ_Proceedings_Jua. 23rd Aug 2001,pp:1-9. Available: http://www.urbanhorticulture.ch/pub/files/89.pdf Accessed on 15th June 2007.

23. Macek, T., M. Mackova and J. Kas, 2000. Exploitation of plants for the removal of organics in environmental remediation. Biotechnology Advances.,18: 23-34. 